\title{
“O TRABALHO VAI SER O ALIMENTO PRA PROLONGAR UM POUQUINHO MAIS A VIDA": ENVELHECIMENTO, MASCULINIDADE E TRABALHO NO PAMPA SUL-RIOGRANDENSE
}

\author{
Liza Bilhalva ${ }^{1}$ \\ Marta Bonow Rodrigues ${ }^{2}$
}

Este ensaio ${ }^{3}$ parte das observações de campo durante a execução da pesquisa do Inventário Nacional de Referências Culturais/INRC- Lidas Campeiras na Região de Bagé/RS ${ }^{4}$ e tem como objetivo apresentar como atores que cresceram e envelheceram no modo de vida campeiro em localidades da campanha ${ }^{5}$ do Rio Grande do Sul se constituíram como sujeitos masculinos. Esses atores são homens que viveram ou vivem em zonas rurais e têm no trabalho um de seus principais elementos constituidores.

O Inventário identificou sete lidas ${ }^{6}$ campeiras que estão interligadas e são interdependentes, ou seja, uma necessita da outra para que ocorra o trabalho campeiro em sua plenitude, e são elas as principais constituidoras do homem campeiro. Esses homens são peões e capatazes campeiros, caseiros, domadores de cavalos, alambradores, esquiladores, tropeiros e guasqueiros (RIETH, RODRIGUES e SILVA, 2015). Os peões campeiros são os homens que desempenham as atividades diretamente relacionadas ao trabalho com o gado, enquanto o capataz é um conhecedor das lidas e é um organizador, um líder dos peões; os caseiros atuam nos serviços ao redor da casa,

\footnotetext{
${ }^{1}$ Universidade Federal do Rio Grande (FURG).

${ }^{2}$ Universidade Federal de Pelotas (UFPel).

${ }^{3}$ Todas as imagens são de autoria individual ou conjunta de membros da equipe do INRC Lidas Campeiras da Região de Bagé e são parte do acervo da pesquisa.

${ }^{4}$ A pesquisa foi uma demanda da Prefeitura de Bagé/RS, e foi realizada entre 2010 e 2013, executada pela Universidade Federal de Pelotas (Departamento de Antropologia e Arqueologia), com metodologia e financiamento do Instituto do Patrimônio Histórico e Artístico Nacional (através do PAC-Cidades Históricas. O objetivo do INRC foi identificar, documentar e construir conhecimento sobre a "lida campeira" para seu registro como Patrimônio Cultural Imaterial brasileiro. A equipe deste INRC foi composta por antropólogas (os) e historiadores: Flávia Rieth (coordenadora), Liza Bilhalva, Marta Bonow Rodrigues, Daniel Vaz Lima, Marília Kosby, Pablo Dobke, além de colaboradoras (es) nas áreas de arquitetura e urbanismo, antropologia da imagem e som, geografia e história.

${ }^{5}$ A campanha é uma microrregião do estado brasileiro do Rio Grande do Sul, e pertence à mesorregião Sudoeste Rio-Grandense. Tem como característica a presença de campos naturais comumente destinados às atividades pastoris e que se estendem para além do território brasileiro, constituindo, este bioma, partes do Uruguai e Argentina. Neste Inventário, entraram na pesquisa as seguintes cidades do Rio Grande do Sul: Bagé, Aceguá, Hulha Negra, Arroio Grande, Piratini, Pelotas e Herval.

“"A lida, no sul do Brasil, é o equivalente ao trabalho diário, às tarefas e práticas laborais, especialmente as manuais. A "lida campeira" é o trabalho rural, o trabalho com animais de produção no campo, no ambiente rural” (BILHALVA \& RODRIGUES, 2017: 115 - nota de rodapé.).
} 
como limpeza, corte de lenha, ordenha das vacas, carneadas ${ }^{7}$, entre outros; os domadores fazem com que os cavalos se tornem mansos para montaria e adequados para o trabalho do campo ou atividades esportivas; os alambradores (ou aramadores) ocupam-se de construir cercas de arames e/ou repará-las; os esquiladores tratam de esquilar ou tosquiar as ovelhas: é o serviço da retirada da lã dos animais nos períodos de calor; os tropeiros levam os animais de um local ao outro, em geral por terra, guiando o gado a pé ou a cavalo; e os guasqueiros são os artesãos que criam artefatos e objetos de couro a serem utilizados na lida campeira.

Essas lidas exigem desses homens um maior ou menor grau de força física, destreza e habilidade. São nessas condições, juntamente com a possibilidade de permanecer no meio rural ou dar continuidade desse modo de vida em contextos urbanos, que esses homens constroem e reconstroem suas masculinidades, um ponto constituinte sensível principalmente com a chegada da aposentadoria e/ou do envelhecimento.

As masculinidades desses campeiros, ainda na atividade das lidas, ou com novas configurações após suas aposentadorias ou migrações para as cidades, estão, portanto, intimamente ligadas a esse trabalho do campo, cujo elemento fundamental são as criações de animais - principalmente bovinos, equinos e ovinos - juntamente com as atividades associadas a esse trabalho (BILHALVA \& RODRIGUES, 2017; RIETH, RODRIGUES e SILVA, 2015; SILVA, 2014).

As características dessas "lidas brabíssimas", de trabalhos perigosos e árduos, que exigem do corpo movimento e destreza, parecem ser os elementos necessários para a formação ontológica desses homens (RIETH, RODRIGUES e SILVA, 2015). Para Leal (1992), o gaúcho ${ }^{8}$ deve exercer a dominação dos elementos da natureza de forma contínua para que se constitua como "homem gaúcho" perante seus semelhantes. O corpo parece ser instrumento fundante dessa masculinidade, pois por meio dele se processam as habilidades necessárias para a constituição desse sujeito (SILVA, 2011).

\footnotetext{
${ }^{7}$ É o abate artesanal de animais, com a confecção de cortes de carnes a serem armazenadas para posterior consumo. Esses animais para consumo nessa região, habitualmente são ovinos, bovinos e suínos, além de aves domésticas.

${ }^{8}$ Nesse caso, a autora define o gaúcho como o homem que vive nas atividades do campo no Rio Grande do Sul, com algumas características determinantes como a dominação da natureza, o trabalho com os animais, a provação de seus atributos masculinos a seus pares homens gaúchos. Para o presente ensaio, utilizamos o conceito "homem campeiro" desenvolvido no âmbito da pesquisa do INRC aqui citado, que indica a categoria "trabalho" como a constituidora do modo de vida.
} 
Essas lidas, construtoras ontológicas desses homens, são, também, as limitadoras dos corpos envelhecidos. Assim, esses homens, quando na impossibilidade de montar a cavalo - importante elemento para constituição do sujeito masculino campeiro ou do gaúcho sobre o qual nos fala Leal (1992) -, de puxar um arame na cerca, de derrubar um touro por meio do laço, buscam em outras atividades os elementos que os mantém inseridos no mundo campeiro. O corpo do indivíduo, através de suas várias idades, se transforma ao longo do tempo, e essas transformações dão sentido às experiências nas suas trajetórias de vida (SILVA, 2011). E as lidas campeiras por suas características duras, acabam contribuindo para um envelhecimento mais rápido do corpo. Enquanto o corpo aguenta, os trabalhos no campo continuam sendo realizados, algumas vezes com auxílio de homens mais jovens para as atividades mais pesadas (Figuras 1 a 10). Quando doenças e senilidade incapacitam, há o afastamento dos trabalhos diretos no campo, com a nostalgia dos tempos "brabos" e aproximação com ao vida campeira por outras vias.

[...] depois não pude trabalhar mais, operei, o doutor me tirou o cavalo, me tirou todo o serviço, não posso fazer mais nada. A máquina não dá mais, a pressão é muito alta, mas vou levando. A lida no campo era boa e ruim. Marcação é coisa boa. Participava, gostava de tirar laço, hoje não sei se prestaria para alguma coisa, nem caminhar ligeiro não posso. Tenho saudade. De não fazer as coisas fico doente, andar a cavalo, domar [...]" "[...] sou doente por baile até hoje. Na terceira idade formamos a terceira idade, tivemos um grupo. Vou ao CTG mas não danço mais agora, ia pra fora CTG de Herval, Jaguarão, Pelotas, Porto Alegre, viajava bastante, depois fui deixando, não posso mais calçar mais [...]. (Seu Macyr Recuero, 78 anos ${ }^{9}$, 2011).

[...] o trabalho vai ser o alimento, assim pra moral, pra prolongar um pouquinho mais a vida. Se tu para...Ih... Trabalho que eu digo ó, é uma ocupação, né? Porque, que trabalho vai ser? Então eu fiz isso aí, fui montando, montando, montando (ACERVO CAMPEIRO). Agora já tá pequeno. Só sobre o campeiro, sobre a parte campeira. Porque eu me criei no campo. Meu pai era campeiro, meu avô era do campo. A descendência toda era campeira. Então a gente guarda aquilo [...]. Quando a gente chega a essa idade, eu tenho 85 anos, aquilo começa vir à cabeça da gente, né, e a gente até se sente assim, feliz, tá pensando no passado, né [...] (Seu Neri Canhada, 85 anos, 2011).

Os estigmas que o envelhecimento sofre em geral são potencializados pela questão da perda da capacidade corporal de desempenhar as atividades do campo: o "estar velho" é não ter mais as condições físicas exigidas para a lida campeira, é "quando o corpo forte e viril usado como instrumento de dominação, perde sua força e, portanto, a utilidade para o trabalho" (SILVA, 2011: 3). Segundo Le Breton (2011: 11),

\footnotetext{
${ }^{9}$ A idade do interlocutor, bem como as idades de todos os outros que aqui aparecem são as informadas na época da pesquisa, durante as entrevistas e captação das imagens.
} 
"a condição humana é corporal, o homem é indiscernível do corpo que lhe dá a espessura e a sensibilidade de seu ser no mundo". Assim, há a necessidade de reconfigurar essa condição e manter o campo em seus corpos através de atividades diversas e passíveis de serem desenvolvidas nessa nova realidade.

O corpo envelhecido, em conjunto com a aposentadoria e, ainda, a falta de aplicação de leis trabalhistas que mantenham esses sujeitos no meio rural, afasta-os das lidas mais árduas do campo, fazendo com que busquem outras alternativas para suas manutenções e reconstruções como sujeitos campeiros masculinos (SILVA, 2014).

Algumas dessas atividades estão no âmbito rural e são mais pontuais, sem excessos de exigências do corpo, como a aplicação de medicamentos durante um manejo sanitário dos animais (Figuras 11) - o que é parte da lida cotidiana, mas não exige tanto esforço físico, a lida com animais a pé - já que o cavalo é um dos principais causadores de lesões na coluna e pernas (Figuras 12 e13), ou a confecção e/ou reparação de artefatos em couro utilizados na lida campeira, pelo guasqueiro do campo (Figuras 14 e 15$)$.

No meio urbano, carregam fortemente o vínculo com o campo, através de atividades que incluem o cuidado com cavalos em hospedarias localizadas nas periferias das cidades (Figuras 16 e 17), o artesanato em couro - atividade profissional ou amadora do guasqueiro que pode ser realizada na cidade (Figuras 18 e 19), a criação e manutenção de "museus caseiros" - acervos de materiais campeiros (Figura 20), a produção de livros com contos e poesias que tratam da temática campeira, a atividade de músico cantando e escrevendo sobre o modo de vida campeiro (Figura 21), a participação em desfiles característicos de datas comemorativas com temática gaúcha e campeira, o ensino a seus filhos e netos sobre as lidas campeiras (Figura 22) e a participação em bailes de $\mathrm{CTG}^{10}$ com música nativista ${ }^{11}$, como citado por Seu Macyr, entre tantos outros meios de se aproximar e vivenciar o campo, habitando o meio rural ou urbano.

\footnotetext{
${ }^{10} \mathrm{CTG}$ - Centros de Tradições Gaúchas, sociedades civis que cultivam a cultura e os costumes do Rio Grande do Sul, a partir de registros feitos por folcloristas reconhecidos pelo movimento tradicionalista gaúcho, sofrendo transformações ao longo do tempo, porém mantendo suas bases tradicionais.

${ }^{11}$ Música nativista é um termo atribuído às músicas dos repertórios não-tradicionais do Rio Grande do Sul e, por vezes, de Santa Catarina e Paraná, porém que carregam temas do trabalho campeiro (ou gaúcho) em suas letras, em ritmos comumente tocados em bailes e festas, ou mais lentos, intimistas e nostálgicos para apenas apreciação do ouvir. Esses temas comuns são: o campo, a culinária campeira, o romance, a paisagem, os animais, etc.
} 
As redes de relações atuam nesse movimento, no qual observamos os interlocutores tecendo e igualmente sendo tecidos/envolvidos nas tramas da rede que se forma a partir dos novos contextos experienciados. E, assim, vão construindo cotidianos, relações e, sobretudo, a si mesmos. A partir dos aspectos subjetivos e simbólicos é possível evidenciar as conexões estabelecidas entre campo e cidade, passado e presente, humanos e não humanos, trabalho e modo de vida e se constituírem como homens masculinos envelhecidos ou em processo de envelhecimento.

Desta forma, é permitido pensar que o aspecto relacional que envolve homens, mulheres, animais, objetos e paisagem neste universo cultural, constituem os sujeitos e por sua vez, as práticas culturais. O trabalho na sua concepção mais ampla (trabalho da memória, trabalho da honra, trabalho das emoções e dos sentimentos, trabalho da negociação de realidades) é o que parece construir a identidade de gênero masculina e, por sua vez, acaba por semantizar a cultura campeira em contextos em transformação: "[...] Quando a gente chega aqui [cidade], a gente tem que se adaptar. Tem coisas que eu não largo, mas outras a gente negocia [...]” (Clair Almeida, 2013).

Assim, na rede que seguimos cujas tramas nos mostraram os caminhos, encontramos esses homens que, estabelecendo conexões heterogêneas, articulando diversas tempos e naturezas, lidando com novos contextos, constroem-se na relação com o novo, com o vivido, com as "coisas" e com a memória coletiva que os transcendem.

A ruptura espaço-temporal no mundo do trabalho e, consequentemente, como em alguns casos, a migração dos campeiros para os centros urbanos, acaba por implicar na (re)configuração das práticas sociais a partir de um campo de possibilidades oriundo da experiência do vivido e do pensado.

[...] Mas é diferente, o homem do campo que sai da toca e vem pra cá [cidade] enlouquece. Não enlouqueci porque comigo foi gradativo. O pessoal do campo que está na cidade ajuda a gente a não se perder, e nos ajuda a permanecer fazendo isso que a gente faz [...]. (Clair Almeida, 2013)

[...] O trabalho é a minha vida. Aprendi com meu pai e avô, criei meus filhos e sustentei a família com isso aqui [feitura de artesanato em couro]. Não sei se vou ter para quem deixar, mas representa uma continuação. Isso é a única coisa que liga o gaúcho da cidade ao campo [...]. (Abelardo Meireles, 59 anos, 2013).

O valor da moral e do trabalho parece carregar esses sujeitos através dos caminhos das continuidades/descontinuidades rumo a novas possibilidades de se refazer, articulando as concepções do que é "ser homem/o que faz um homem" com as 
transformações contemporâneas no processo de envelhecimento e, portanto, durar pelas vias das razões práticas e simbólicas.

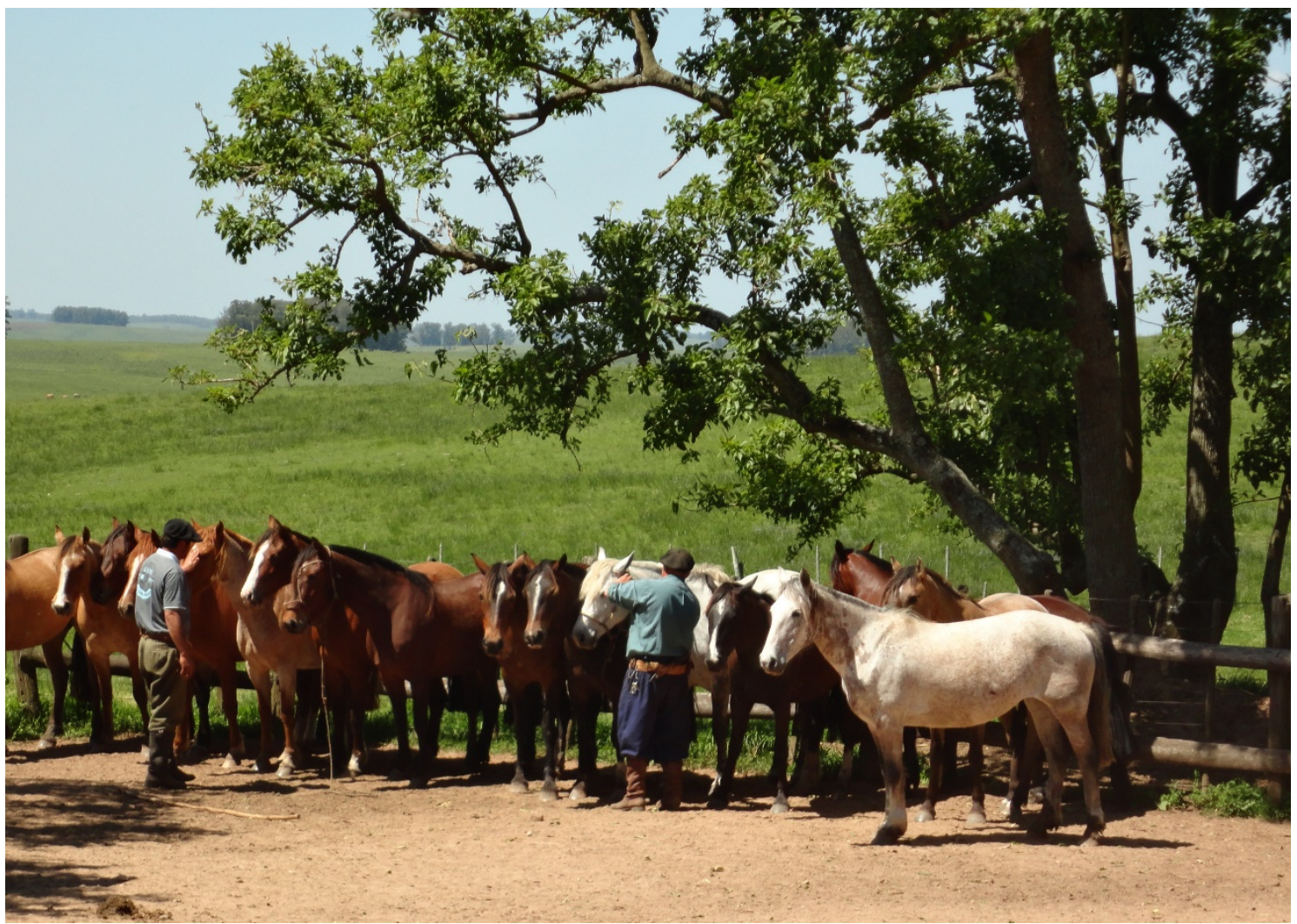

Figura 1 - Seu Brasileiro, capataz da Estância Santa Leontina, pegando o cavalo para a lida com o gado, Aceguá/RS. Foto: Marta Rodrigues - Acervo INRC - Lidas Campeiras na Região de Bagé/RS, 2011. 


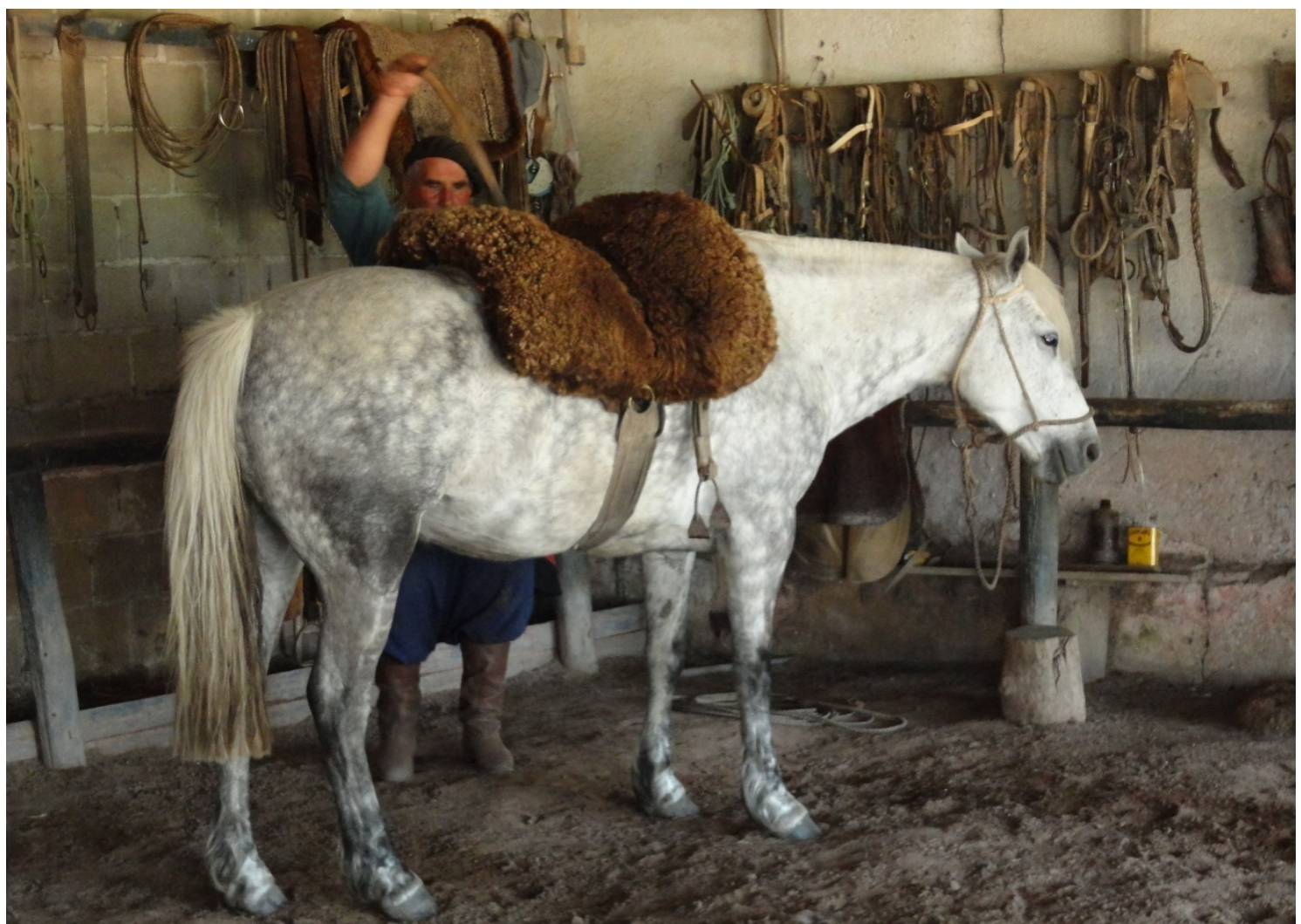

Figura 2 - Seu Brasileiro, capataz da Estância Santa Leontina, encilhando o cavalo para a lida com o gado, Aceguá/RS. Foto: Marta Rodrigues - Acervo INRC - Lidas Campeiras na Região de Bagé/RS, 2011.

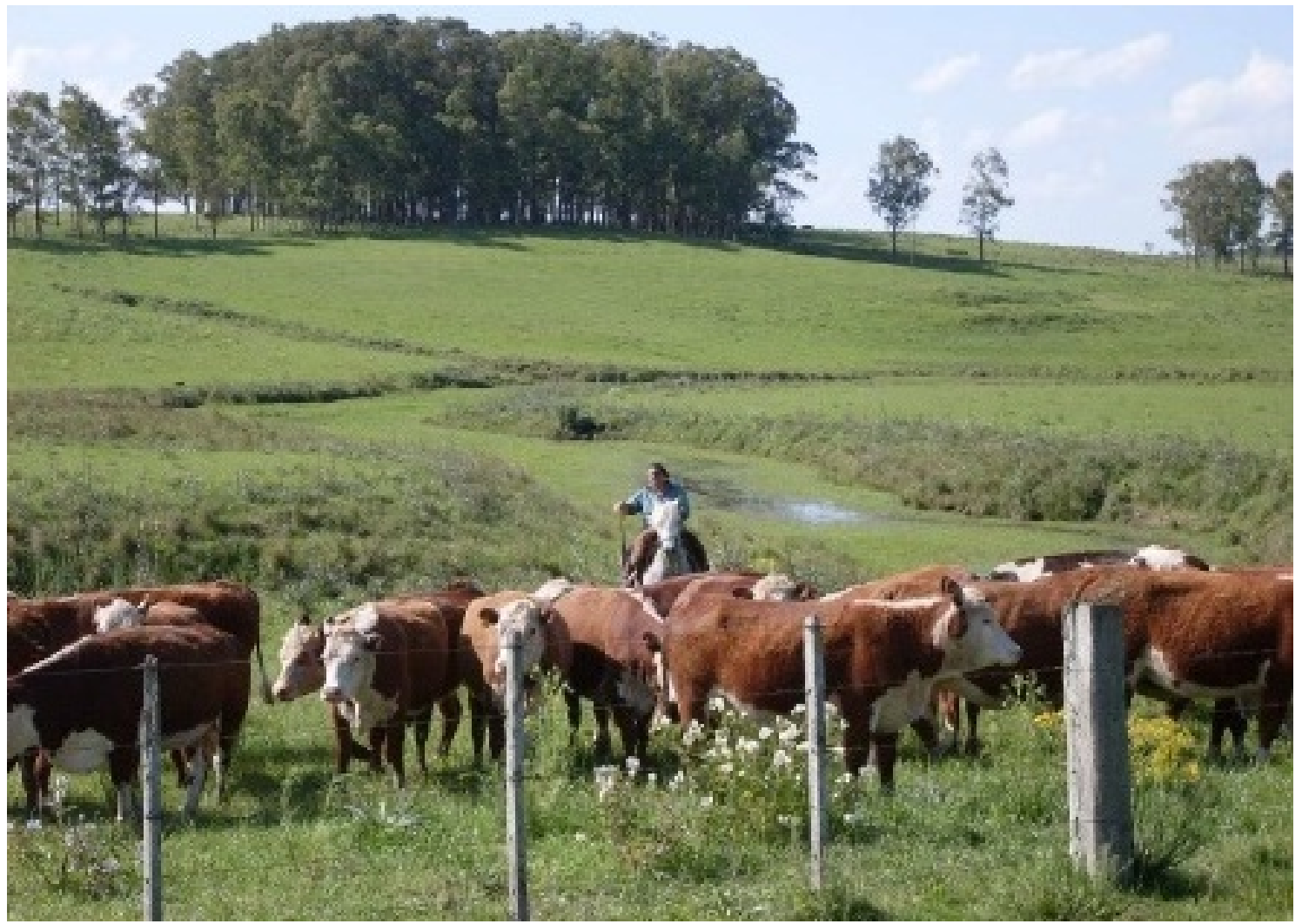

Figura 3 - Seu Brasileiro, capataz da Estância Santa Leontina, durante a lida com o gado bovino, Aceguá/RS. Foto: Acervo INRC - Lidas Campeiras na Região de Bagé/RS, 2011. 
“O trabalho vai ser o alimento pra prolongar um pouquinho mais a vida": Envelhecimento, masculinidade e trabalho no Pampa sul-riograndense

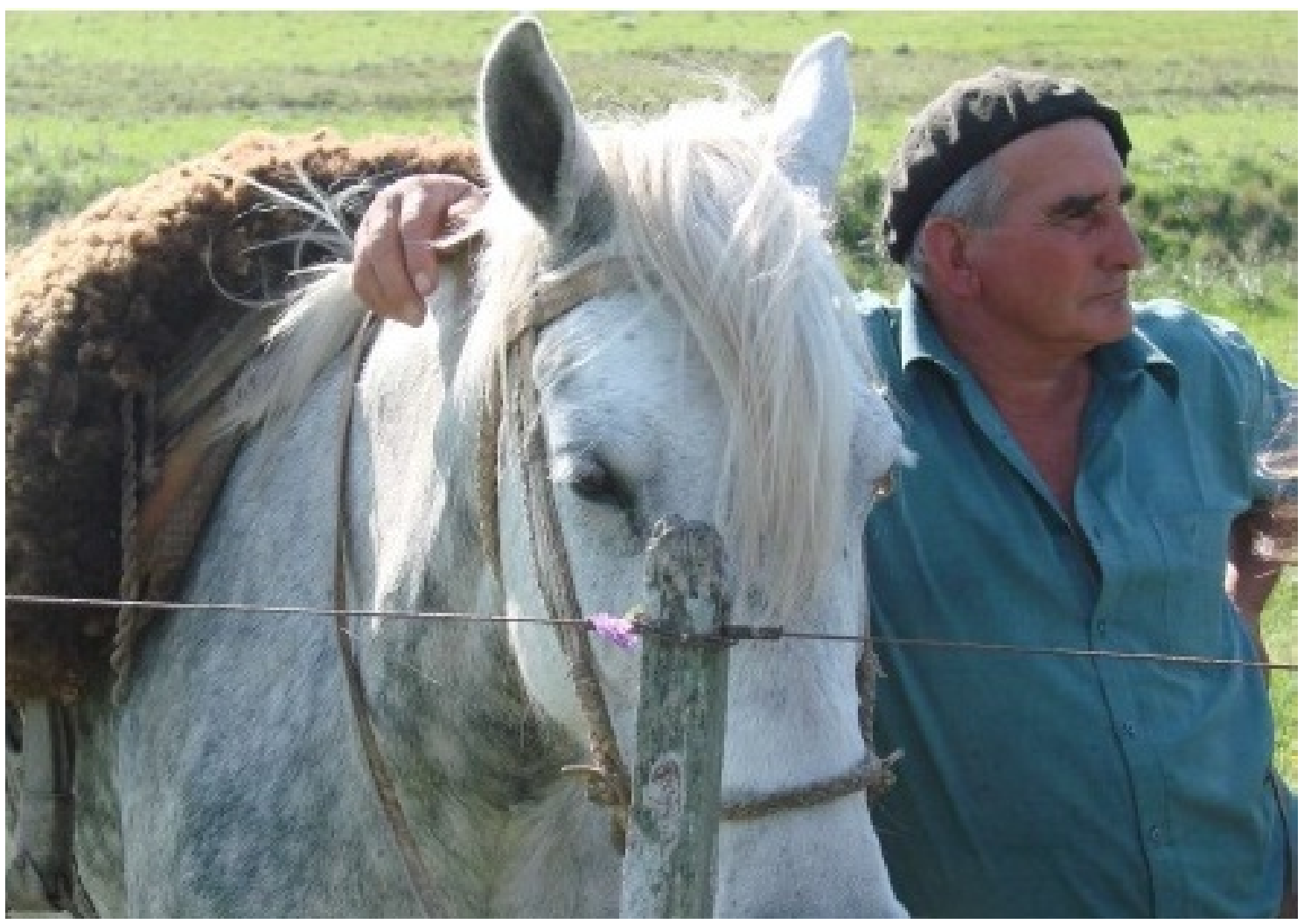

Figura 4 - Seu Brasileiro, capataz da Estância Santa Leontina, descansa enquanto aguarda a passagem do gado bovino para outra divisa do campo, Aceguá/RS. Foto: Acervo INRC - Lidas Campeiras na Região de Bagé/RS, 2011.
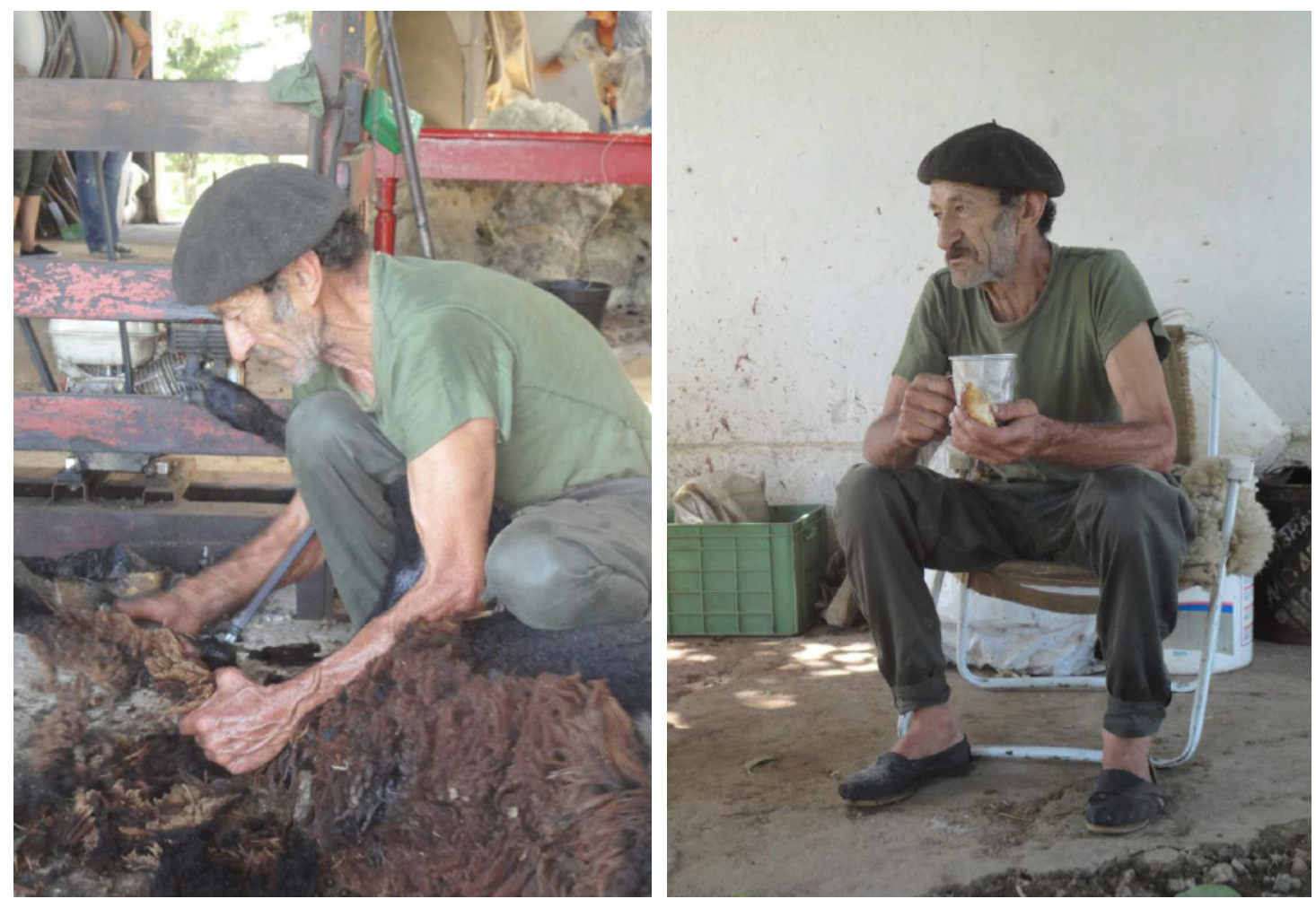

Figura 5 e 6- Trabalhador na esquila de ovelhas e em momento de descanso, Estância Minuano Aceguá/RS Fotos: Acervo INRC- Lidas Campeiras na Região de Bagé/RS, 2012. 


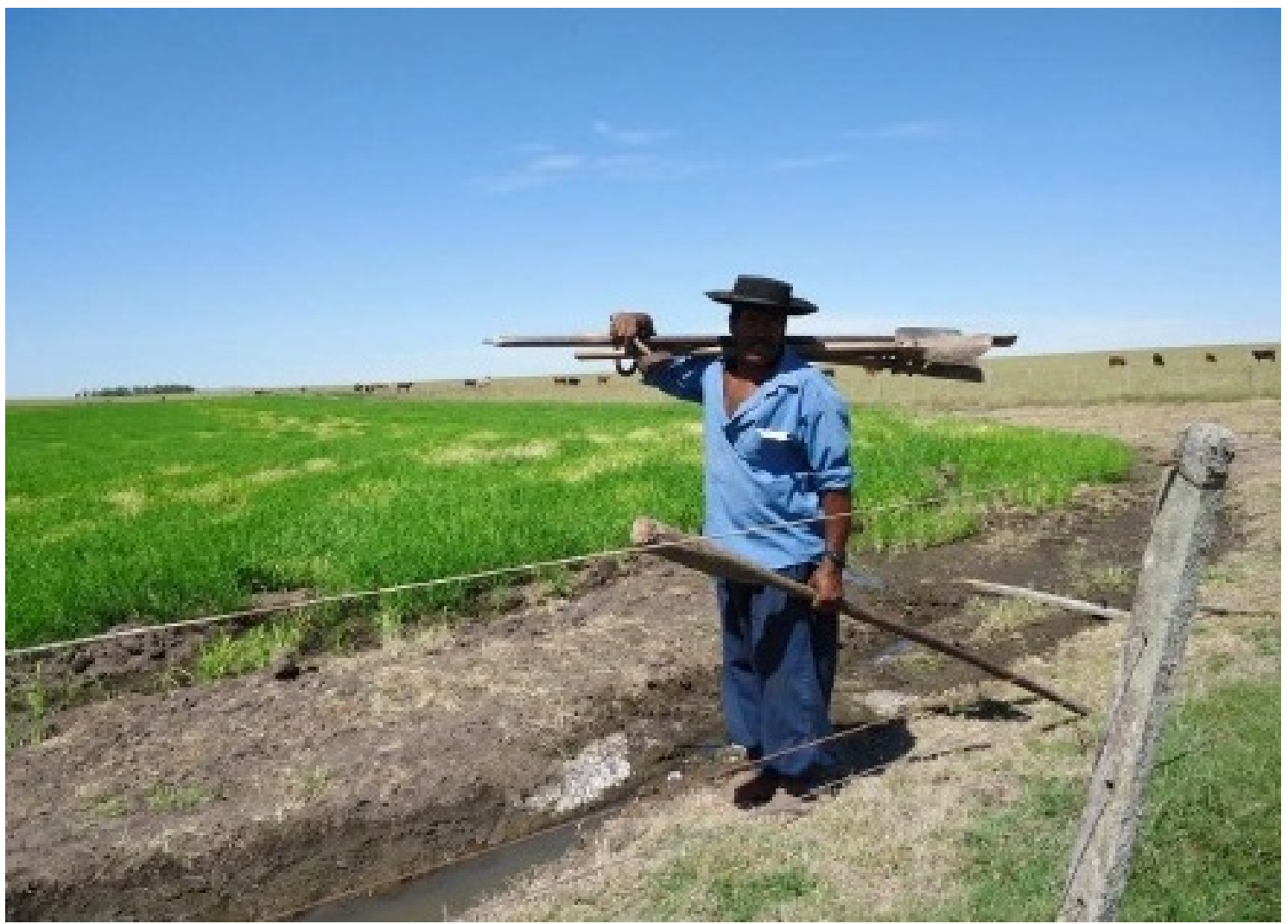

Figura 7 - Seu Ari, 58 anos, alambrador, carregando materiais para refazer aramado de cerca em propriedade rural de criação de gado, Bagé/RS Foto: Acervo INRC- Lidas Campeiras na Região de Bagé/RS, 2012.

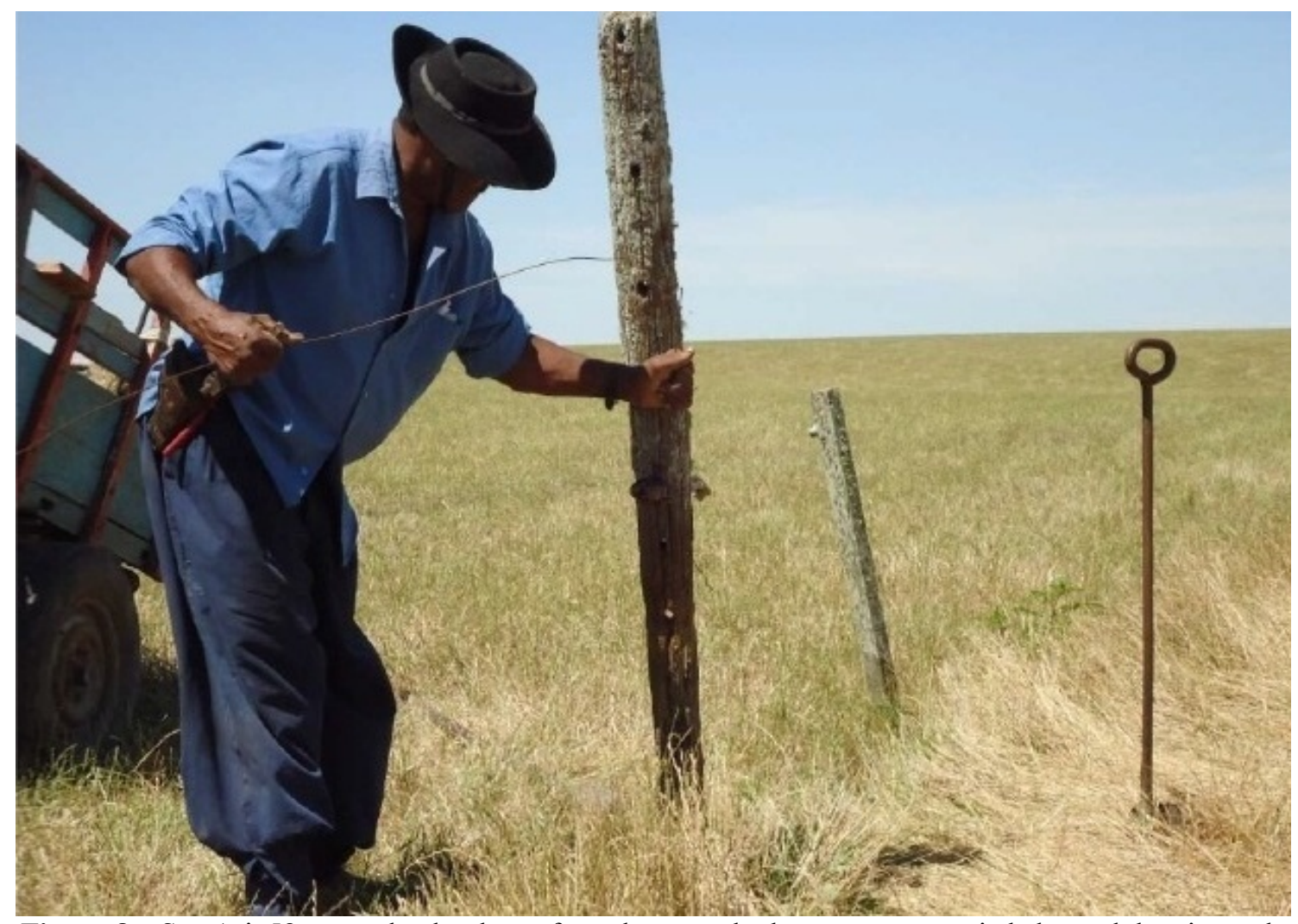

Figura 8 - Seu Ari, 58 anos, alambrador, refazendo aramado de cerca em propriedade rural de criação de gado, Bagé/RS Foto: Acervo INRC- Lidas Campeiras na Região de Bagé/RS, 2012. 


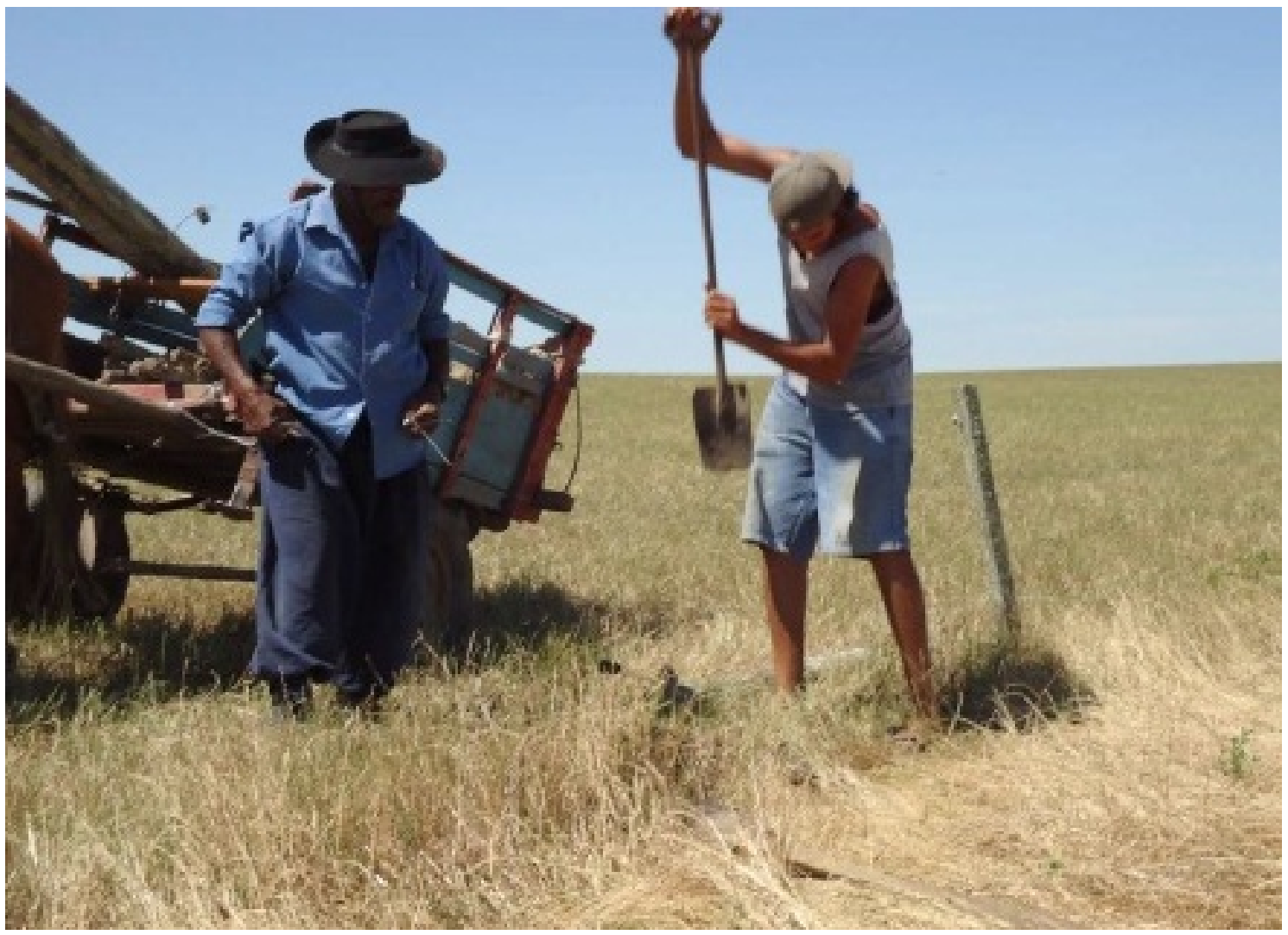

Figura 9 - Seu Ari, alambrador, com seu auxiliar abrindo os buracos na terra para fixação dos piques e postes de madeira que irão compor a cerca de arames, Bagé/RS Foto: Acervo INRC- Lidas Campeiras na Região de Bagé/RS, 2012

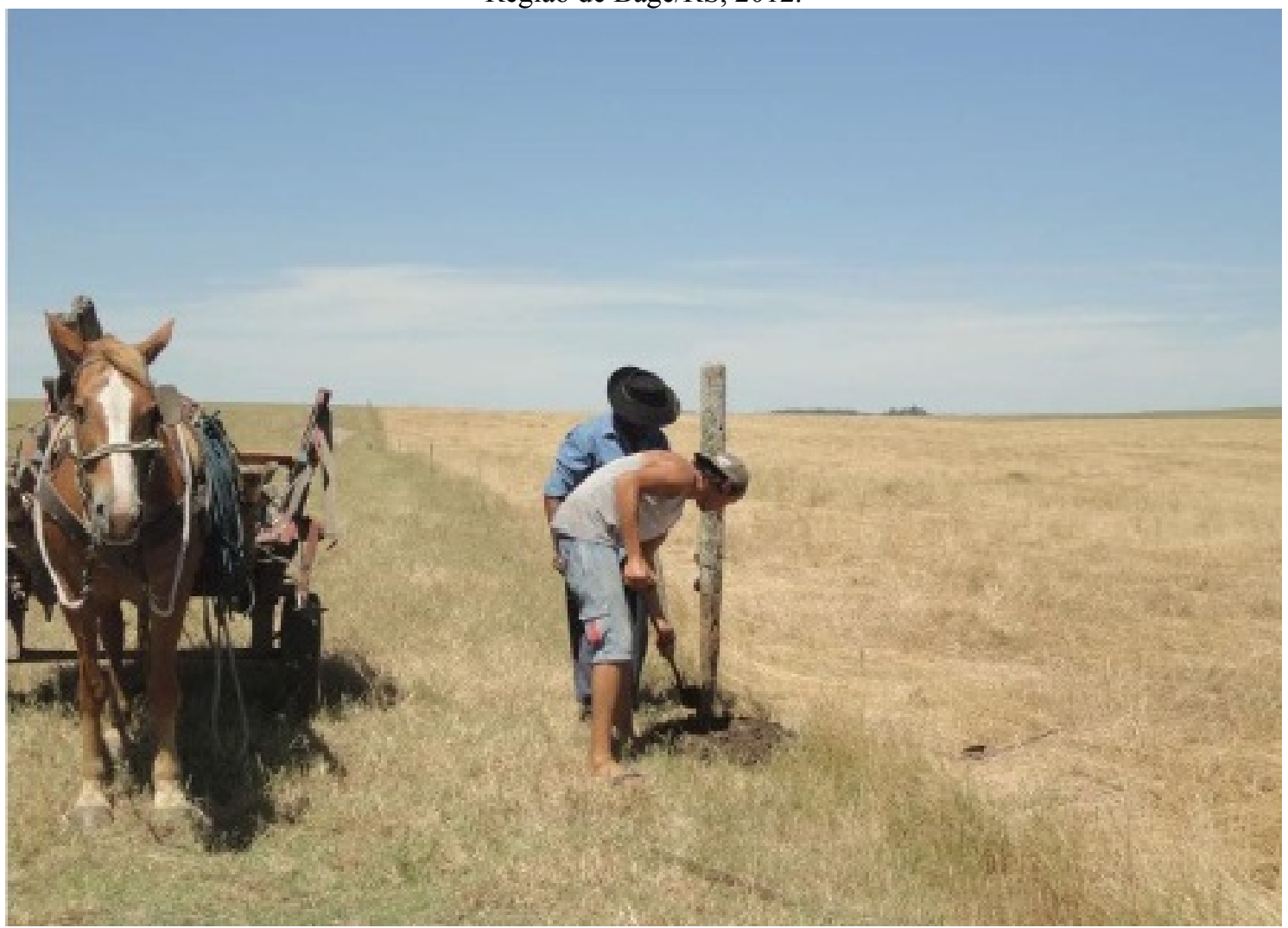

Figura 10 - Seu Ari, alambrador, com seu auxiliar fixando um poste de madeira que irá compor a cerca de arames, Bagé/RS Foto: Acervo INRC- Lidas Campeiras na Região de Bagé/RS, 2012. 


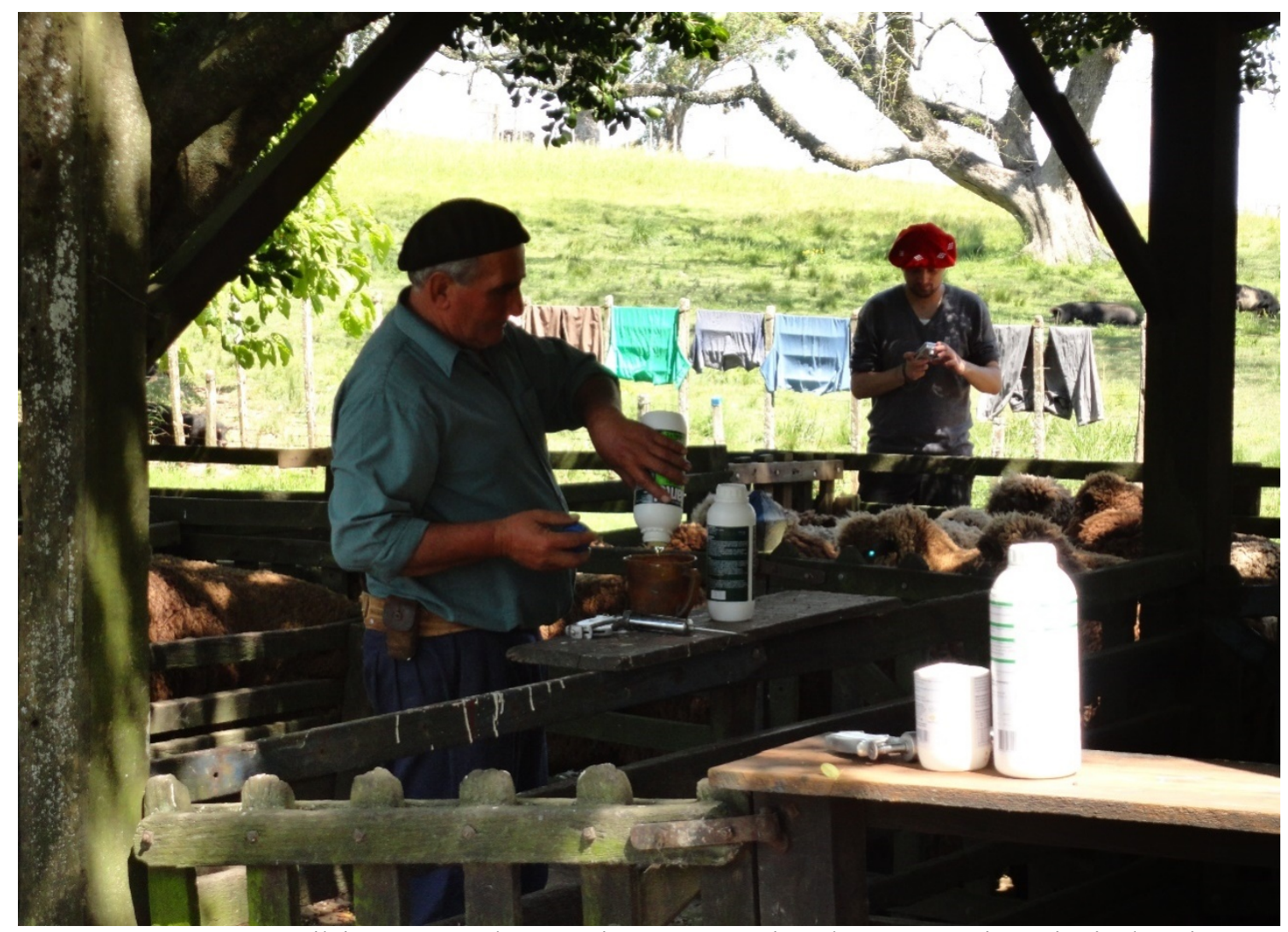

Figura 11 - Seu Brasileiro, capataz da Estância Santa Leontina, durante manejo sanitário de ovinos, Aceguá/RS. Foto: Marta Rodrigues - Acervo INRC - Lidas Campeiras na Região de Bagé/RS, 2011.

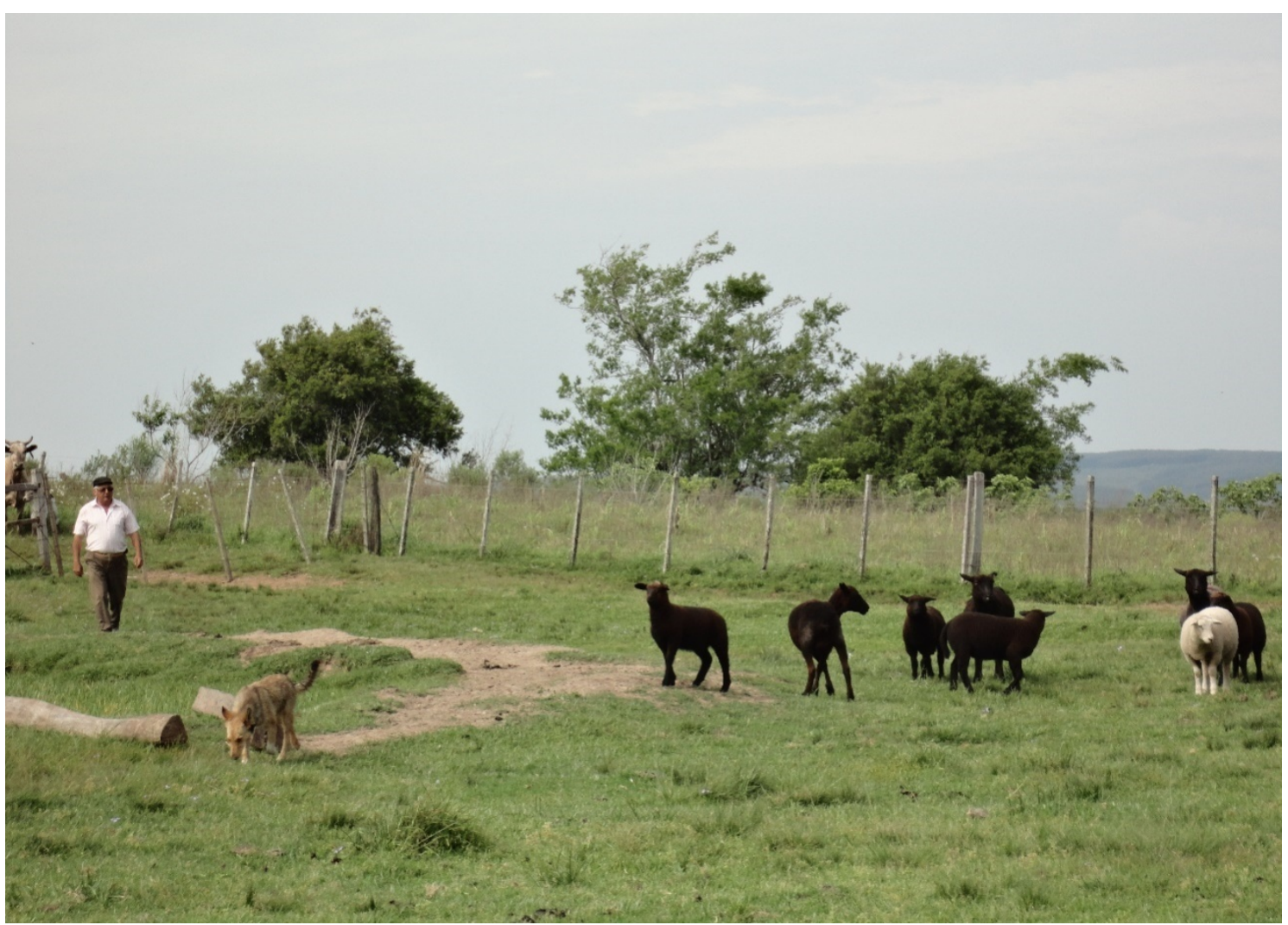

Figura 12 - Seu Edemar (in memorian), pequeno proprietário rural na localidade de Palmas, lidando com 
“O trabalho vai ser o alimento pra prolongar um pouquinho mais a vida": Envelhecimento, masculinidade e trabalho no Pampa sul-riograndense

o rebanho ovino a pé, Bagé/RS. Foto: Marta Rodrigues - Acervo INRC - Lidas Campeiras na Região de Bagé/RS, 2011.

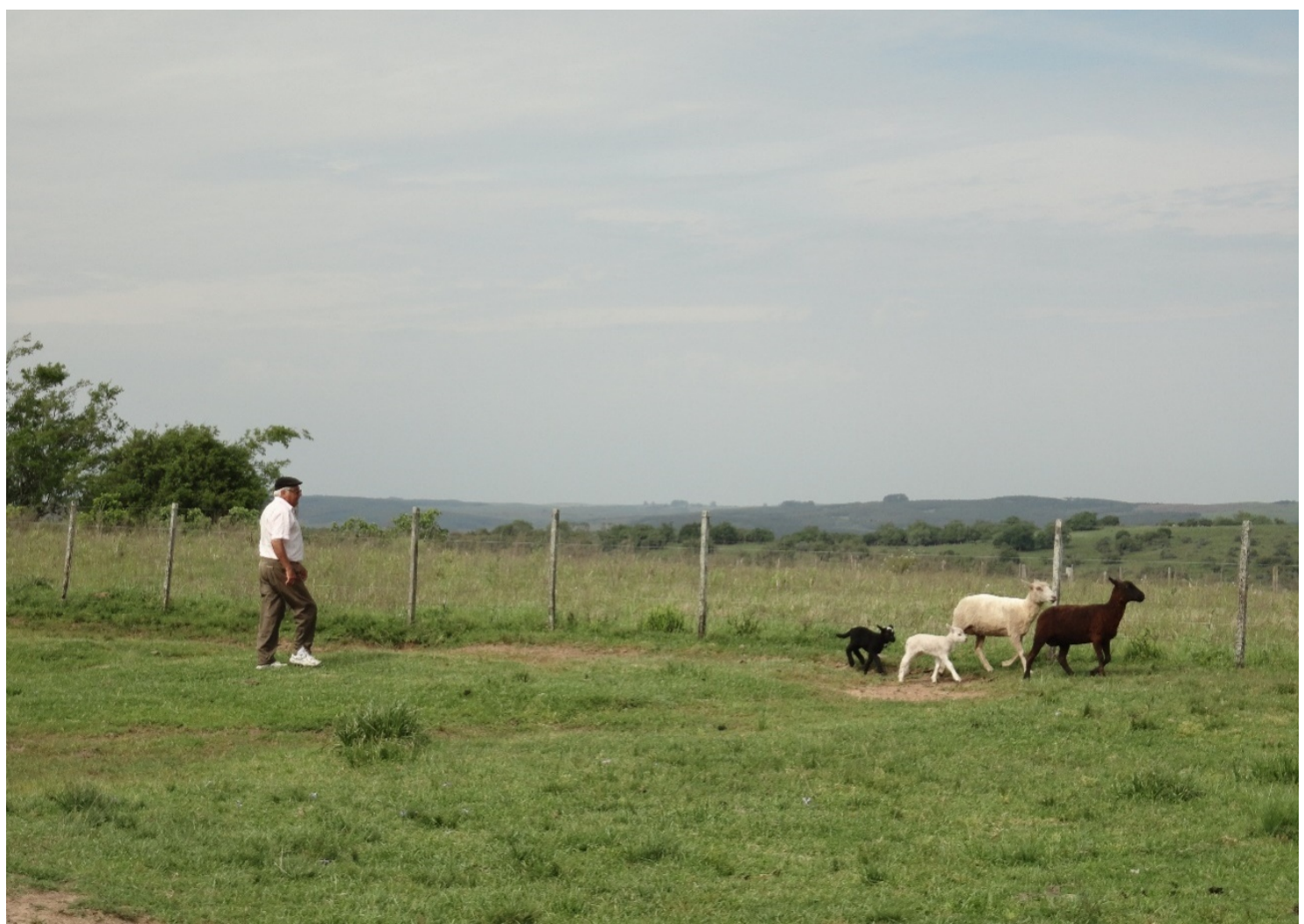

Figura 13 - Seu Edemar (in memorian), pequeno proprietário rural na localidade de Palmas, lidando com o rebanho ovino a pé, Bagé/RS. Foto: Marta Rodrigues - Acervo INRC - Lidas Campeiras na Região de

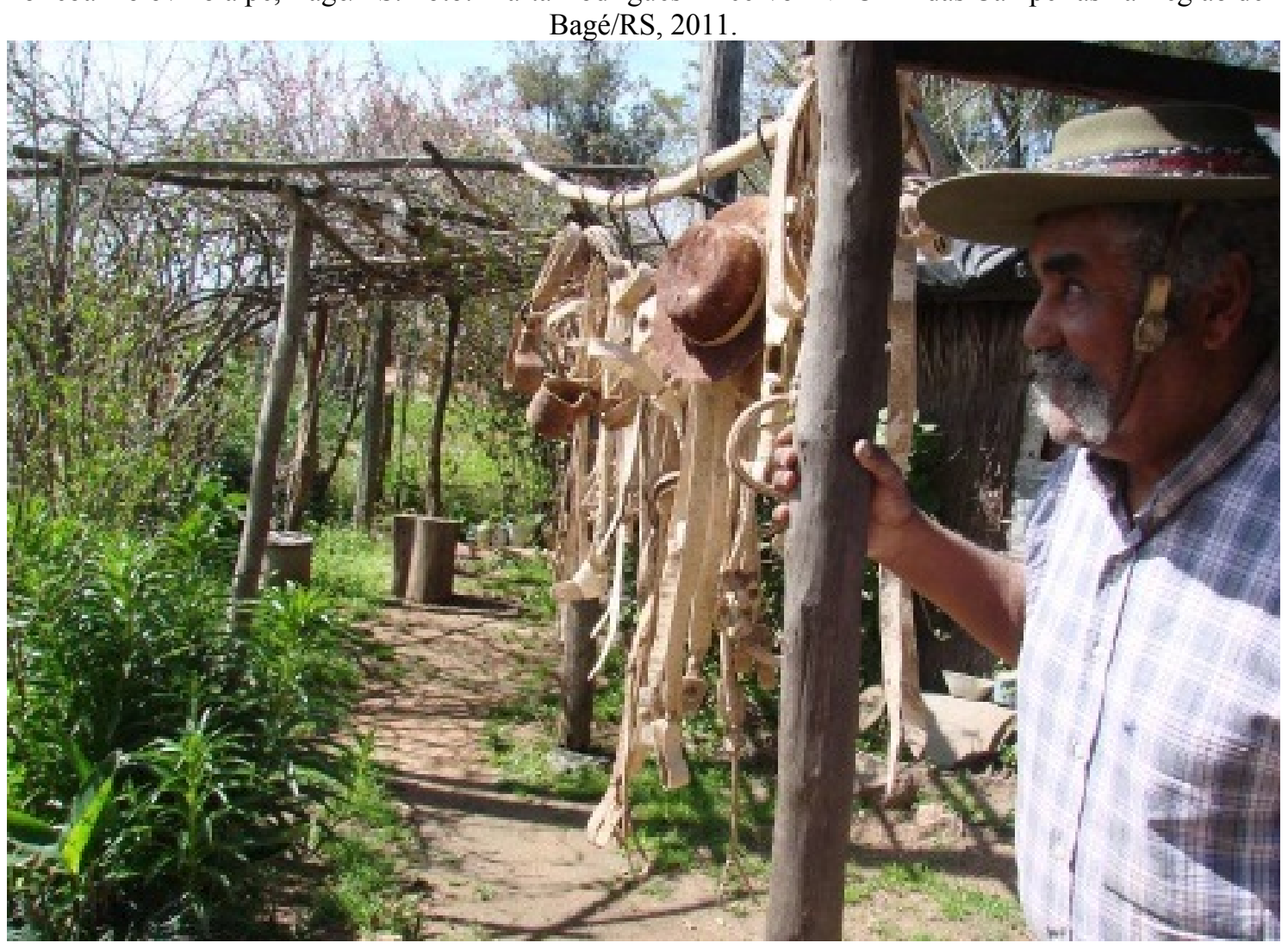


Figura 14 - Seu Ginêz, 75 anos, guasqueiro, com os artefatos produzidos por ele, Vila da Lata -região rural de Aceguá/RS. Foto: Marília Kosby - Acervo INRC - Lidas Campeiras na Região de Bagé/RS, 2011.

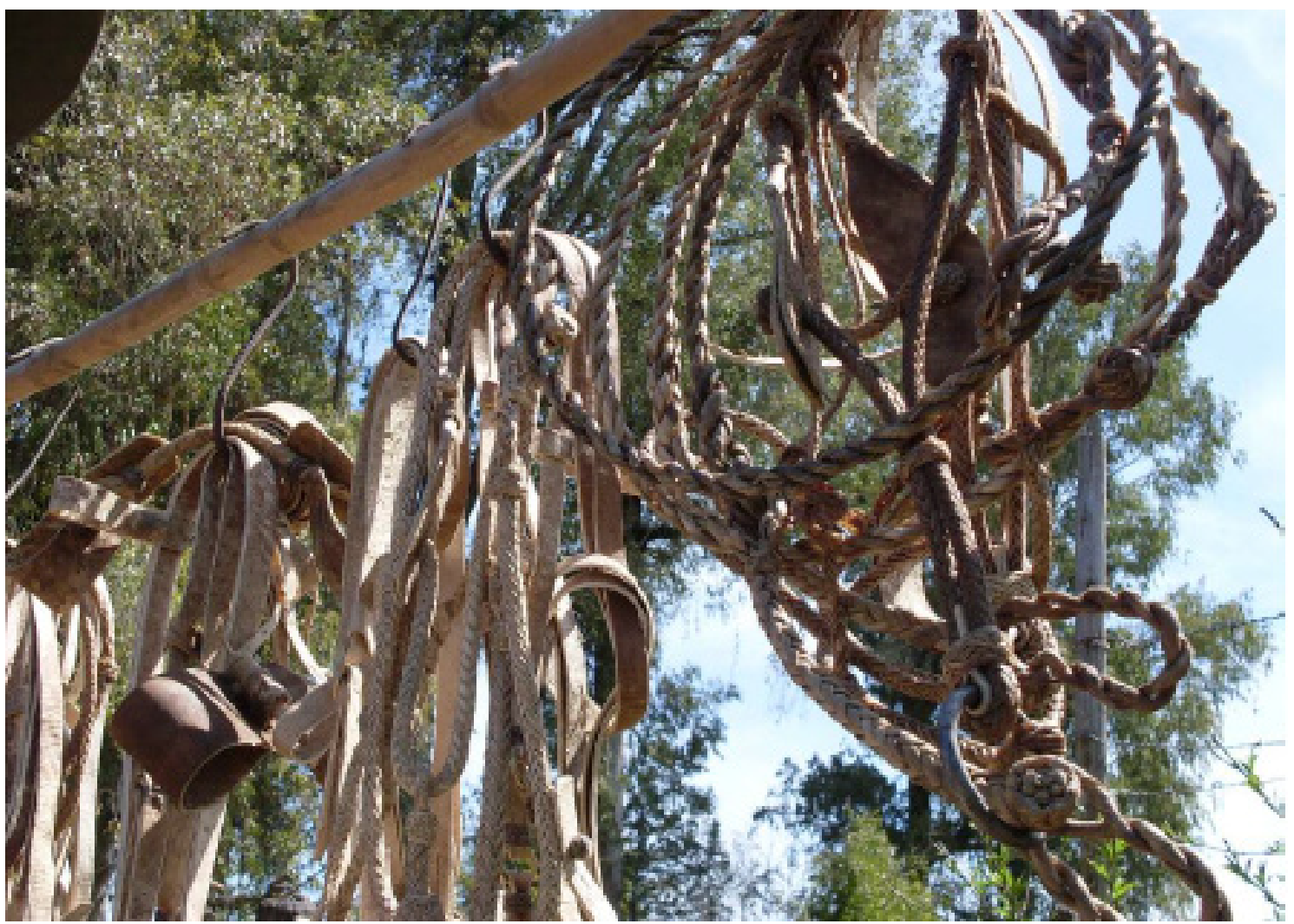

Figura 15 - Artefatos para a lida campeira produzidos em couro pelo artesão Seu Ginêz,75 anos, guasqueiro, Vila da Lata -região rural de Aceguá/RS. Foto: Acervo INRC - Lidas Campeiras na Região de Bagé/RS, 2011. 
“O trabalho vai ser o alimento pra prolongar um pouquinho mais a vida": Envelhecimento, masculinidade e trabalho no Pampa sul-riograndense

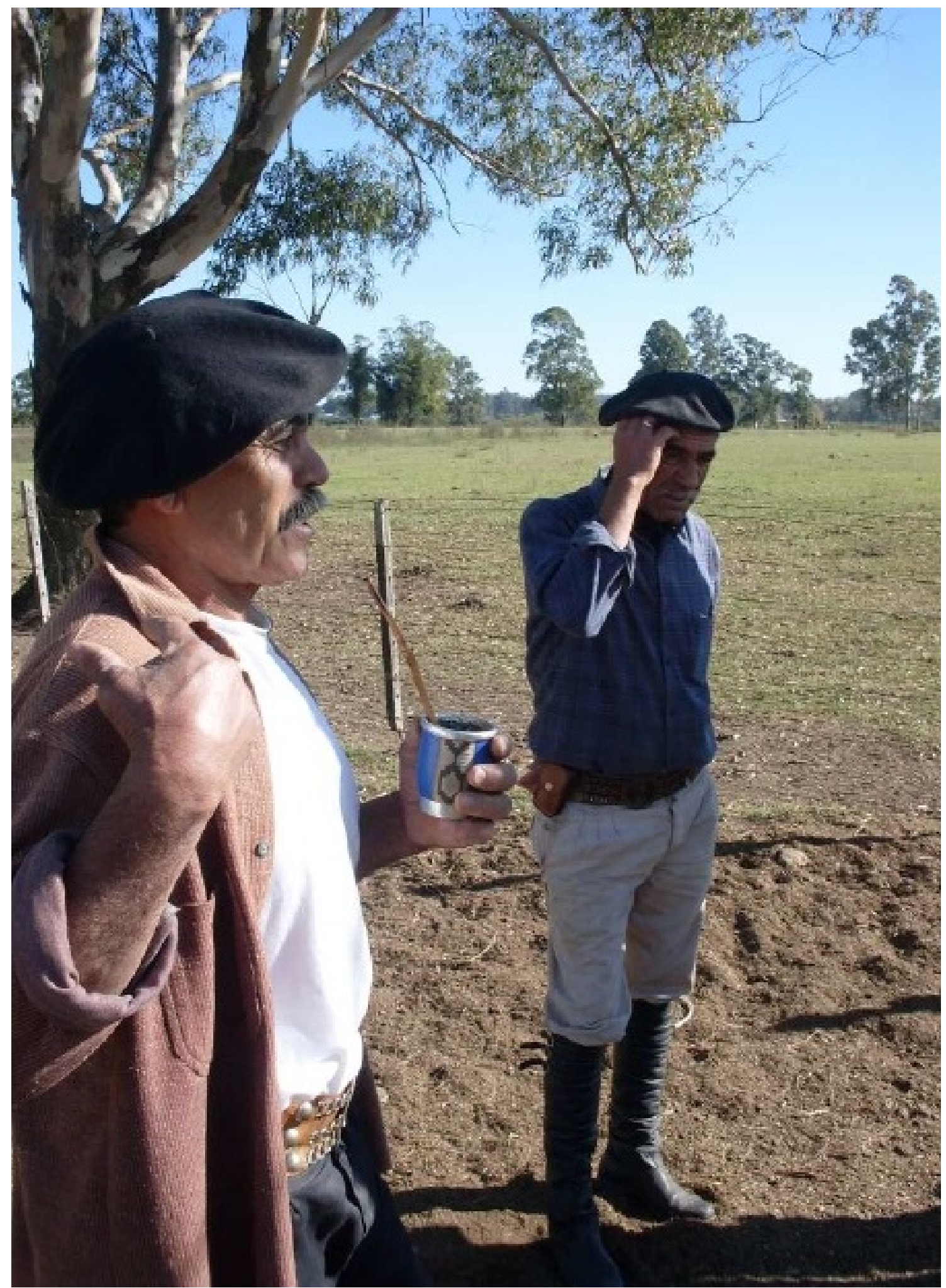

Figura 16 - Seu Beto, 70 anos, e Seu Danilo -trabalhadores rurais aposentados e proprietários de uma hospedaria de cavalos na periferia da cidade de Bagé/RS. Foto: Acervo INRC - Lidas Campeiras na Região de Bagé/RS, 2012. 


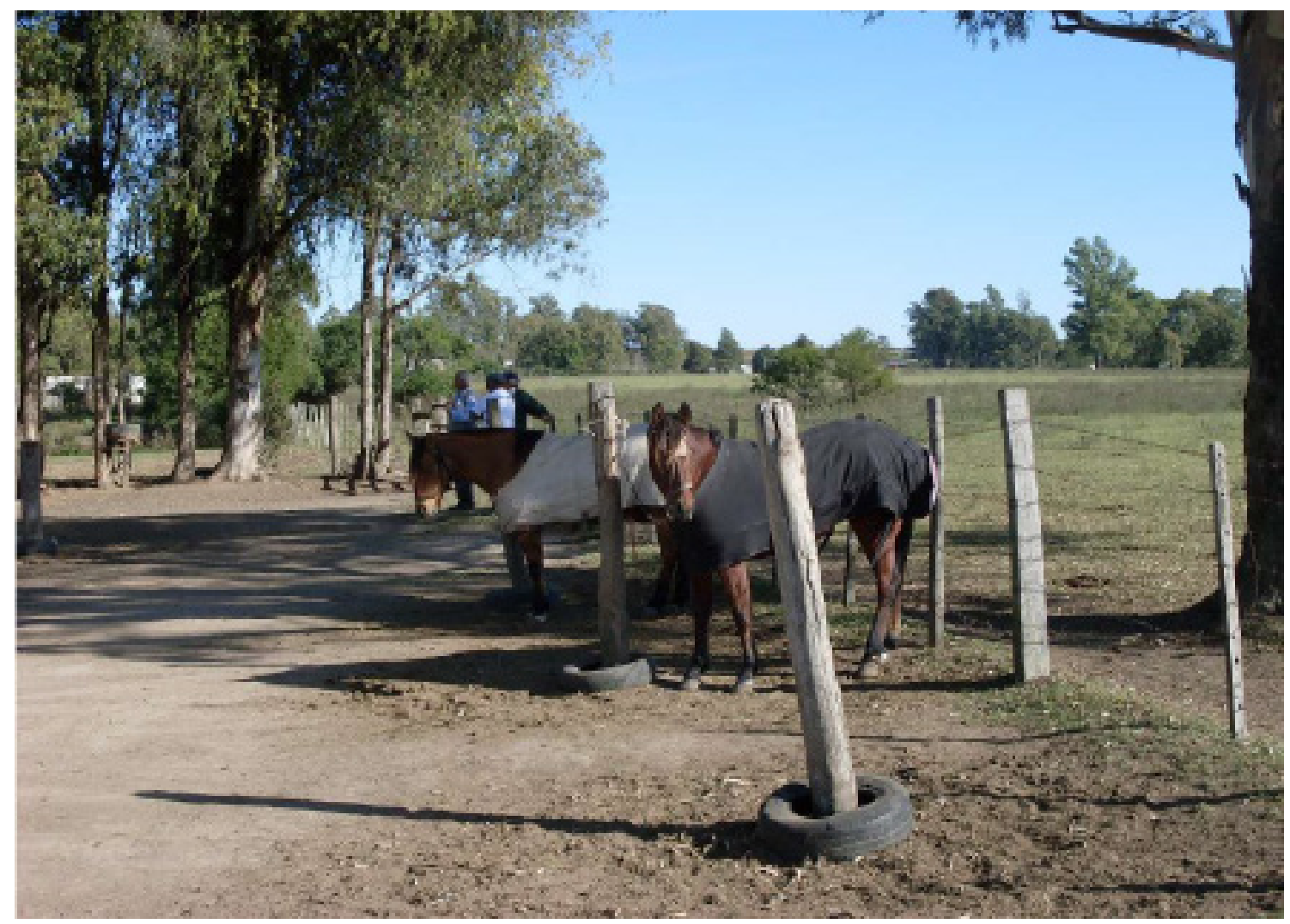

Figura 17 - Cuidado com cavalos na hospedaria de Seu Beto, 70 anos, e Seu Danilo - trabalhadores rurais aposentados, cuidadores de cavalos em uma hospedaria da qual são proprietários na periferia da cidade de Bagé/RS. Foto: Acervo INRC - Lidas Campeiras na Região de Bagé/RS, 2012.
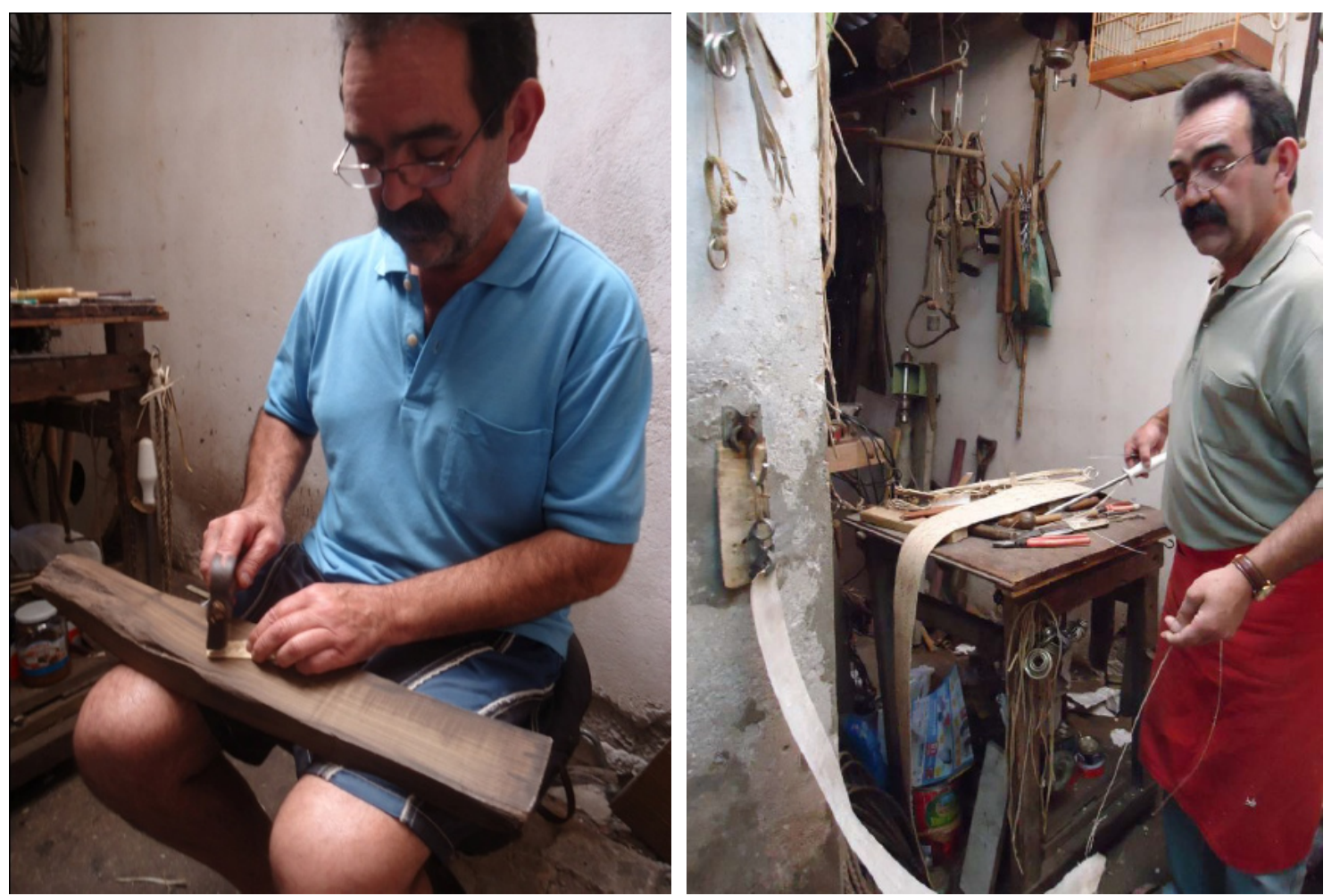

Figuras 18 e 19 - Abelardo ,59 anos, guasqueiro, batendo couro e tirando tentos (finas tiras de couro para costuras e arremates), atividade pela qual se aproxima do campo, mesmo morando na cidade, Pelotas/RS. Fotos: Liza Bilhalva, Acervo INRC - Lidas Campeiras na Região de Bagé/RS, 2012. 

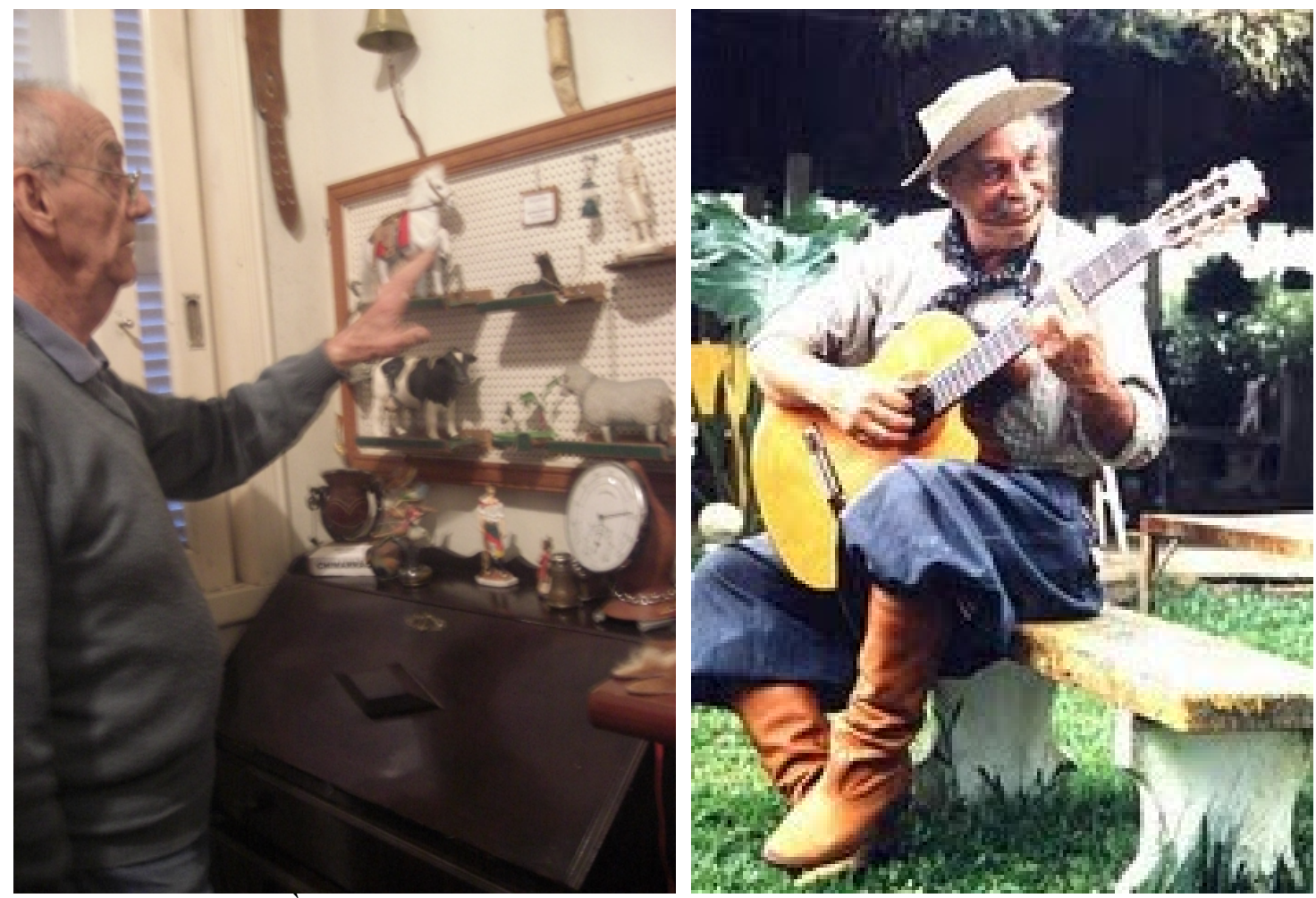

Figuras 20 e 21 - À esquerda: Seu Neri, 85 anos, aposentado, criador e mantenedor de um acervo campeiro, um museu caseiro na cidade, por meio do qual busca guardar as memórias de sua vida no campo, Arroio Grande/RS. Foto: Acervo INRC - Lidas Campeiras na Região de Bagé/RS, 2011; à direita: Eron Mattos, 60 anos, pequeno proprietário rural, aposentado, músico e poeta, Bagé/RS. Foto: Acervo de Eron Vaz Mattos, s/d. 


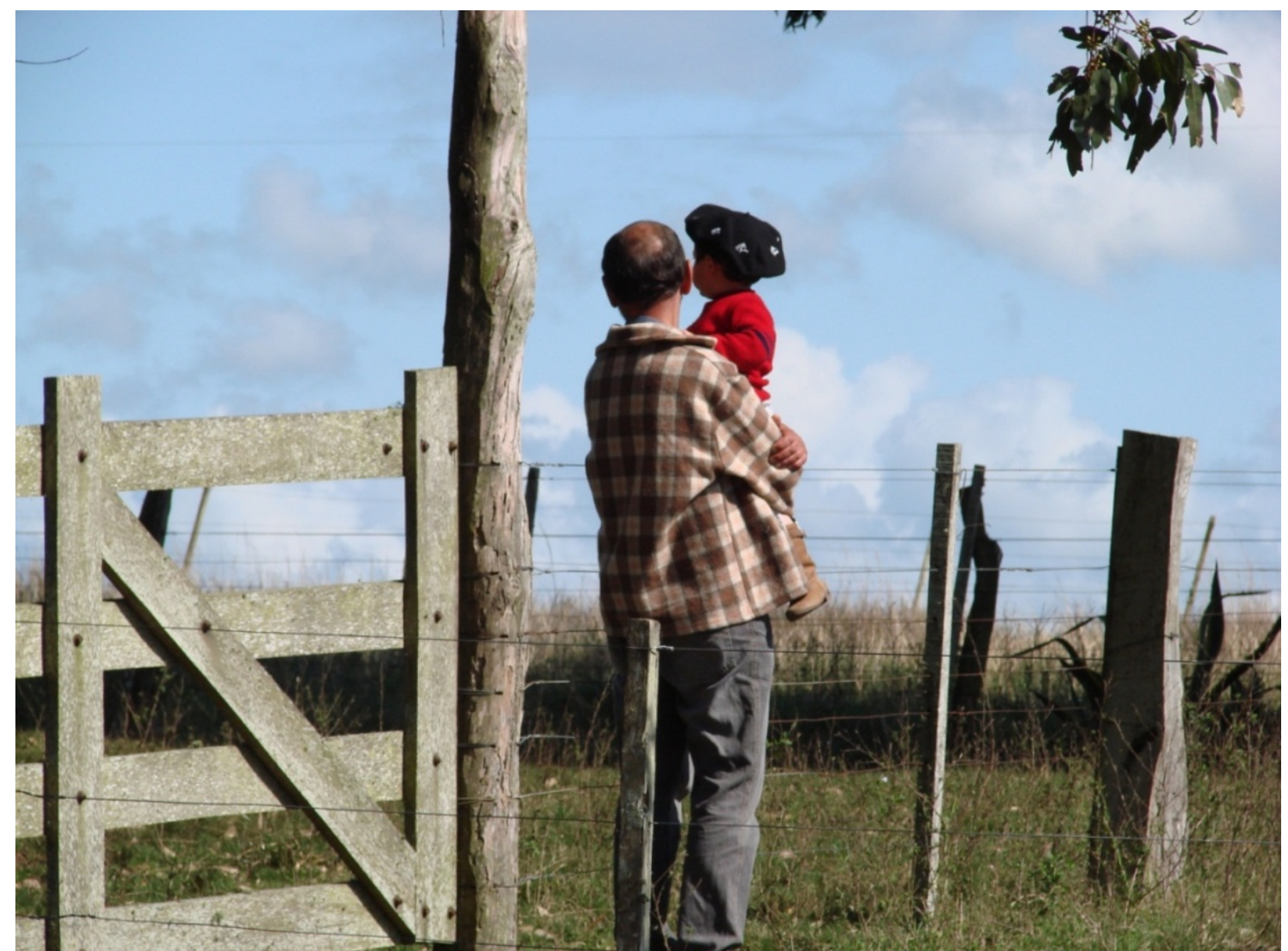

Figuras 22 - Produtor rural mostrando o campo e os animais para seu neto, Bagé/RS. Fotos: Acervo REFERÊNCIAS BIBLIOGRÁFICAS

BILHALVA, Liza; RODRIGUES, Marta Bonow. Artefatos como suportes de memória na construção da masculinidade no Pampa Sul-Riograndense. Tessituras, Pelotas, v. 5, n. 2, jul-dez/2017, p. 113-141.

LE BRETON, David. Antropologia do corpo e modernidade. Petrópolis, RJ:Vozes, 2011.

LEAL, Ondina. O Mito da Salamandra do Jarau: constituição do sujeito masculino na cultura gaúcha. Revista Psiquiatria. 14(1), jan-abr/1992, p. 8-11.

RIETH, Flávia M. S.; RODRIGUES, Marta B.; SILVA, Liza B. M. da. As lidas campeiras na região de Bagé/RS: sobre as relações entre homens, mulheres, animais e objetos na invenção da cultura campeira. In: NUMMER, Fernanda V.; FRANÇA, Maria Cristina C. C. (Org.). Entre ofícios e profissões: reflexões antropológicas. Belém: GAPTA/UFPA, 2015, p. 175-195.

SILVA, Liza B. M. Masculinidade, memória e trabalho: um estudo etnográfico com homens campeiros do pampa sul-rio-grandense em processos de mobilidade. Tessituras, Pelotas, v. 1, n. 1, 2013, p. 123-149.

. Entre lidas: um estudo de masculinidade e trabalho campeiro na cidade. 2014. 128 f. Dissertação (Mestrado em Antropologia) - Programa de Pós-Graduação em Antropologia, UFPel, [2014]. 
SILVA, Liza B. M.; RIETH, Flávia M. S. Masculinidade, corpo e velhice na região pampeana do Rio Grande do Sul. XX Congresso de Iniciação Científica e III Mostra Científica da UFPel. Anais do XX Congresso de Iniciação Científica e III Mostra Científica da UFPel,

http://www2.ufpel.edu.br/cic/2011/anais/pdf/ch/ch_00172.pdf

Recebido 23/04/2019

Aprovado 28/05/2019 